\title{
КОНТРАСТИРАҢЕ НА ПЕРФЕКТОТ ВО АНГЛИСКИОТ И ВО МАКЕДОНСКИОТ ЈАЗИК
}

\author{
Марина Новакоска \\ Меѓународни училишта „Нова“, Скопје \\ novakoska.marina@yahoo.com
}

Предмет на оваа статија е контрастирање на формата и употребата на англискиот перфект (present perfect simple) и англискиот траен перфект (present perfect continuous) од една страна и македонскиот перфект од друга страна. Контрастивната анализа се базира на податоци од неколку истражувања, како и на податоци преземени од Македонскиот корпус на англискиот меѓујазик (МКАМ), кој претставува електронска база на текстови продуцирани од изучувачи на англискиот јазик. Целта е да се утврдат сличностите и разликите помеѓу англискиот и македонскиот перфект. Резултатите од контрастивната анализа може да се користат во наставата по англиски јазик. Поаѓајќи од претпоставката дека македонскиот јазик влијае врз процесот на усвојување на англискиот перфект и англискиот траен перфект, оваа статија укажува на типичните проблеми со коишто македонските изучувачи се очекува да се соочуваат при изучувањето на двете споменати категории.

Клучни зборови: англиски перфект, македонски перфект, контрастивна анализа 


\title{
CONTRASTING THE PERFECT IN ENGLISH AND IN MACEDONIAN
}

\author{
Marina Novakoska \\ Nova International Schools, Skopje \\ novakoska.marina@yahoo.com
}

The paper presents the results of the contrastive analysis between present perfect simple and present perfect continuous in English, and the perfect in Macedonian in order to determine the similarities and differences between these tenses. The analysis is based on data from various sources, as well as on the data from The Macedonian English Learner Corpus (MELC), which is an electronic database containing texts produced by learners of the English language. The results of the contrastive analysis provide new insights useful in English language teaching. Relying on the assumption that the Macedonian language influences the acquisition process of present perfect simple and present perfect continuous, this article points out the typical problems that Macedonian learners are expected to face while studying the two categories under examination.

Keywords: present perfect, Macedonian perfect, contrastive analysis 


\section{1 Вовед}

Предмет на овој труд е контрастирање на формата и употребата на англискиот перфект (present perfect simple) и англискиот траен перфект (present perfect continuous) од една страна и македонскиот перфект од друга страна. Контрастивната анализа се врши на тој начин што најпрво се дава опис на перфектот и трајниот перфект во англискиот јазик и на перфектот во македонскиот јазик. Потоа се дава преглед на податоците добиени од неколку истражувања коишто ја дискутираат оваа проблематика. Анализата е поткрепена и со податоци за пишан јазик на изучувачи, кој е дел од македонскиот корпус на англискиот меѓујазик (МКАМ). Целта е да се определат сличностите и разликите помеѓу перфектите во двата јазика, како и семантичките еквиваленти на англискиот перфект и англискиот траен перфект во македонскиот јазик. Тоа ќе послужи за дефинирање на хипотезите: кои значења на перфектот и трајниот перфект потешко се усвојуваат од страна на македонските изучувачи, а кои полесно. Сознанијата од ваквата анализа даваат одредени индикации за наставата по англиски јазик, кои би требало да придонесат за нејзино подобрување во насока на полесно и побрзо усвојување на перфектот и трајниот перфект.

\section{2 Теориски основи}

Помеѓу перфектните конструкции во англискиот и во македонскиот јазик постојат одредени сличности и разлики. Во однос на формата, постои структурна паралела помеѓу англискиот перфект и македонскиот имаперфект, бидејќи и двата се формираат со посесивен глагол и пасивен минат партицип. Меѓутоа, македонскиот перфект има уште два конкурентни формални претставника: $c y м$-перфектот и третиот перфект. Формата на англискиот траен перфект, пак, потполно се разликува од формите на македонскиот перфект, бидејќи ги содржи двата помошни глаголи have и be и сегашниот партицип.

Што се однесува на употребата, во овој труд се зема предвид класификацијата дадена од страна на Комри (Comrie 1976), според која сите функции на англискиот перфект се поделени во четири групи:

- Резултативен перфект кој искажува сегашна состојба што настанала како резултат на некоја мината ситуација (He has been cured. 'Tој е излечен.'); 
- Искуствен перфект кој искажува одредена ситуација која до сегашниот момент се случила барем еднаш во некој недефиниран период од минатото (Sam has been to America. 'Сем бил во Америка.');

- Континуативен перфект кој се употребува за искажување на дејство кое започнало во минатото и продолжува во сегашноста (We have lived here for ten years. 'Ние живееме овде 10 години.');

- Перфект кој искажува блиско минато, односно опишува ситуација која се случила во блиското минато (Bill has just arrived. 'Бил само што пристигна.').

Што се однесува на трајниот перфект, во овој труд се разгледуваат двете основни значења презентирани од страна на Раден и Дирвен (Radden and Dirven 2007) и Квирк и др. (Quirk et al. 1985):

- Едната употреба на трајниот перфект се однесува на привремена состојба или навика која започнала во минатото и продолжува да трае во сегашноста, па затоа има актуелна релевантност (I have been studying English for over a year. 'Учам англиски повеќе од една година.'). Говорителот става акцент на времетраењето на привремената состојба или навика, кое обично се специфицира со временски прилог.

- Другата употреба на трајниот перфект се однесува на сегашна состојба предизвикана од некој претходен настан. Сегашната состојба не е експлицитно изразена, туку е имплицирана. Таа се подразбира така што говорителот се фокусира на процесот на траење на дејството. Така, реченицата I have been working all day 'Pабойев иел gен' имплицира дека говорителот е изморен.

Како што беше и претходно спомнато, значењата на перфектот во македонскиот јазик се изразуваат со три вида перфект и тоа: сум-перфект, има-перфект и т.н. трет перфект. Според Конески (1987), сум-перфектот изразува минат настан, при што времето на случувањето обично не е специфицирано, како и сегашна состојба која е резултат на некое минато дејство, односно актуелна релевантност.

Во склоп на има-перфектот пак, Митковска и Бужаровска (2011: 58-60) изделуваат три вида, во зависност од функцијата.

- Посесивно-егзистенцијалниот перфект (ПЕ-перфект) ја нагласува сегашната состојба, додека минатиот настан кој ја предизвикал таа состојба се става во втор план (Тие имаай куйено убав авйомобил). Во овој вид перфект помошниот глагол има имплицира посесивност. 
- Перфектот на актуелната релевантност, исто така, ја потенцира сегашната состојба, но „минатиот настан кој довел до таа состојба доаѓа повеќе во фокусот“(ibid, 59) (Ние gейално г̄о имаме анализирано $\bar{u}$ роек $\bar{u} о \bar{u})$. Најчесто глаголите во има-перфектот искажуваат некакво достигнување.

- Искуствениот перфект става акцент на сегашната релевантност на некое минато искуство на субјектот. „Дејството се случило најмалку еднаш пред сегашниот момент, така што на субјектот може да му се припише некакво знаење што се должи на тоа искуство“ (ibid, 60).

Третиот перфект го содржи помошниот глагол сум и минатиот пасивен партицип кој се добива од непреодни глаголи и секогаш се согласува по род и број со подметот Тие се веќе стииг̄нат̄и (Mitkovska and Bužarovska 2008). Оваа структура има „изразено резултативно статично значење“ и наоѓa широка примена во југозападните дијалекти (ibid, 130). Во другите дијалекти третиот перфект се употребува само за изразување на ситуации во кои резултативното значење е особено нагласено, како на пр. умрен $е$ 'he is dead'(Graves 2000: 489).

\section{3 Претпоставки}

Во фокусот на ова истражување се следниве истражувачки прашања:

- Во кои значења англискиот перфект се преклопува со македонскиот перфект?

- Во кои значења англискиот траен перфект се преклопува со македонскиот перфект?

- Кои значења на англискиот перфект и на англискиот траен перфект македонските изучувачи најлесно ги совладуваат, а кои најтешко?

Кога зборуваме за употреба на англискиот перфект и на англискиот траен перфект од страна на македонски изучувачи, неминовно се наметнува претпоставката дека во процесот на изучување, македонските изучувачи прават споредба помеѓу англискиот и македонскиот перфект. Хипотезата од која поагаме во ова истражување е дека мајчиниот јазик влијае врз процесот на усвојување и употребата на англискиот перфект и англискиот траен перфект од страна на македонските изучувачи. Се претпоставува дека таму каде што има поклопување на значењата на перфектот во двата јазика, македонскиот јазик ќе има позитивно влијание врз совладувањето и примената на англискиот перфект и англискиот траен 
перфект. Од друга страна, повеќе грешки се очекуваат кај оние употреби на перфектот и на трајниот перфект кои во македонскиот јазик се изразуваат со други конструкции, а не со перфектот. Тука постои претпоставка дека македонскиот јазик ќе има негативно влијание.

\section{4 Контрастивна анализа на перфектот во англискиот и во македонскиот јазик}

\section{1 Контрастирање на англискиот перфект (present perfect simple) и македонскиот перфект}

Англискиот перфект (present perfect simple) се преклопува со сум-перфектот во значењата: резултативност (актуелна релевантност) и искуство. Во истите значења англискиот перфект се преклопува и со има-перфектот. Кога англискиот перфект опишува сегашен резултат од некое минато дејство (актуелна релевантност), во македонскиот јазик може да се преведе со сум-перфектот или со има-перфектот. На пример, англиската реченица $I$ have forgotten the tickets for the concert може да се преведе со македонската реченица 'Сум ги заборавила картите за концертот' или, пак, со реченицата 'Ги имам заборавено картите за концертот'. Меѓутоа, на англискиот резултативен перфект одговара и македонскиот аорист. Аористот изразува дејство коешто се комплетирало во минатото и се резултирало во некаква сегашна состојба. Затоа, како што може да се забележи во примерите на Арсова-Николиќ (1980: 245), аористот е преведен со англискиот перфект:

(1) Се наgевам gека gобро му објасни, вели мајкайа.

(Црвено Рондо, Б. Иванов 1964:14)

'I hope you've explained things to him well, the mother says'.

(The Red Rondo, B. Ivanov1975: 321)

Арсова-Николиќ (1980: 273) пишува и за сегашна релевантност на дејство коешто се случило во минатото и коешто било трајно, како во пример (2), или повторливо, како во пример (3). Ваквите дејства во македонскиот јазик се означени со имперфект, а во англискиот јазик со перфект.

(2) Секог̄аш се каев шим̄о г̄о найравив ӣоа.

'I've always regretted having done that.'

(3) Чесӣо се наgевав и намеравав gа gојgам, но ме сиречуваа многуу околностии. 
'I have often hoped and intended to come but have been prevented by many circumstances.' (цитирано во Quirk et al. 1972: 96)

Истражувањето на Бужаровска и Митковска (Bužarovska and Mitkovska 2010) ${ }^{1}$ покажува дека македонските говорители го користат аористот многу повеќе отколку има-перфектот и сум-перфектот за да искажат резултативност, а третиот перфект го користат многу ретко. Овие автори ги издвојуваат контекстите со посесивно-егзистенцијален перфект (4) и тие со перфект на актуелна релевантност (5). Во нивното истражување функцијата на посесивно-егзистенцијалниот перфект во најголемиот број случаи $(52,3 \%)$ била пренесена со аорист, во $40,2 \%$ од примерите оваа функција била пренесена со има-перфектот, а во 7,5\% од случаите со сум-перфектот. Функцијата на перфектот на актуелна релевантност најчесто била пренесувана со аорист (во $72 \%$ од случаите), а потоа со имаперфект (во 13\% од случаите), со сум-перфект (во 12,2\% од случаите) и со третиот перфект (во 2,8\% од случаите). Следниве примери се преземени од прашалникот спроведен од Бужаровска и Митковска (ibid, 88-89).

(А йрг̄нува на gолг̄ йай со сйара кола.

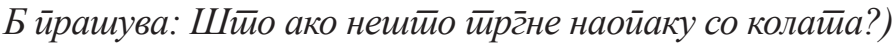

А: Јас КУПУВА резервни делови ако нешйо се расийе

(ги имам со мене).

Во оваа реченица $72 \%$ од испитаниците го употребиле глаголот куйува во аорист, а $28 \%$ од нив го употребиле има-перфектот (ibid).

(5) (Прозорещой е ойворен, но А не забележува и г̄о йрамува Б:

Зошйо е ииолку сйудено во собайа?)

- (Jас) гоо ОТВОРА йрозорецоти.

Во оваа реченица $88 \%$ од испитаниците го употребиле глаголот ойвора во аорист, $3 \%$ во сум-перфект, 3\% во имперфект, $2 \%$ од испитаниците го употребиле овој глагол во има-перфект, а 4\% го употребиле во предминато време (ibid).

Земајќи ја предвид резултативната функција на аористот, како и резултатите од истражувањето на Бужаровска и Митковска (Bužarovska and Mitkovska 2010), претпоставувам дека македонските изучувачи ќе бидат под влијание на македонскиот јазик и ќе го користат англиското минато просто време наместо перфектот за да искажат сегашна релевантност на минато

1 Податоците наведени подолу се добиени од анализата на резултатите од спроведениот прашалник. 
дејство. Такви примери се присутни и во МКАМ. Следниве реченици се преземени од корпусот.

(6) My sister broke her head. Now is in hospital.

'Сестра ми ја повреди главата. Сега е во болница.'

(7) I came back and I bought all that we need.

'Се вратив и купив се што ни треба.'

Кога треба да опишеме искуство, на англискиот перфект му одговара и има-перфектот и сум-перфектот. Во примерот на Арсова-Николиќ (1980: 246) даден подолу, сум-перфектот би можел да се употреби и со тоа потполно да се задржи значењето на реченицата.

(8) Најзначајно е йоа gека навистина има оgлежано зайвор.

(Црвено Рондо, Иванов 1964: 8)

'The most important thing is that she's really been in jail.'

(The Red Rondo, Ivanov 1975: 317)

Во истражувањето на Бужаровска и Митковска (Bužarovska \& Mitkovska 2010: 87), за искажување искуство 57,3\% од испитаниците го искористиле cyм-перфектот, 27\% го искористиле има-перфектот, 8,2\% имперфектот, а 7,5\% од испитаниците го искористиле аористот.

Во МКАМ се наоѓаат многу примери на употреба на формата на перфектот со цел да се искаже некакво искуство $(9,10$ и 11). Изучувачите многу ретко искористиле други конструкции за да го изразат искуствениот перфект.

(9) I have been there some times and it's really good.

'Сум бил таму неколку пати и навистина е добро.'

(10) Everyone has been in some interesting situations during the life.

'Секој се нашол во некоја интересна ситуација во животот.'

(11) In my life I have never betrade a friend.

'Никогаш во мојот живот не сум издала другарка.'

Англискиот перфект не се преклопува со македонскиот перфект во следните значења: дејство што започнало во минатото и продолжува да трае во сегашноста (континуативен перфект) и дејство што означува блиско минато (перфект на блиско минато). Овие значења во македонскиот јазик не 
се искажуваат со перфектот. За опишување дејство кое започнало во минатото и продолжува во сегашноста, македонските говорители користат сегашно време, со што дејството се претставува како несвршено (во одвивање) и се лоцира во сегашноста. Антериорната фаза на дејството не се нагласува. Почетната фаза на дејството или неговото траење може да се прикаже со помош на временска определба. Примерите што следуваат, преземени од Арсова-Николиќ (1980: 182-183, 243), потврдуваат дека македонскиот еквивалент на англискиот континуативен перфект е презентот.

(12) I have been here too long. I want to get away.

(The Great Gatsby, Fitzgerald 1953: 123)

'Тука сум прилично долго. Сакам да одам одовде.'

(Големиой Гејӣзби, Фицџералд 1965: 84)

(13) Jа знаеме Мира оg иелени. (Црвено Ронgо, Иванов 1964: 7)

'We have known Mira since she was in nappies'.

(The Red Rondo, Ivanov 1975: 317)

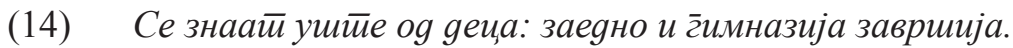

(Тоа Раgиовие во кое йаѓам ялабоко, Павловски 1972: 64)

'They have known each other since childhood:

they left school at the same time.'

(That Radiovce which I sink deep into, Pavlovski 1975: 73)

Во МКАМ детектирани се случаи (15 и 16) во коишто изучувачите ја пренеле функцијата на континуативниот перфект со формата на сегашно просто време.

(15) My school exist for more than 50 years.

'Моето училиште постои повеќе од 50 години.'

(16) We are here a week already.

'Овде сме веќе една недела.'

Врз основа на контрастивната анализа на значењата на перфектот во двата јазика и горенаведените примери, претпоставувам дека македонските изучувачи за да ја изразат функцијата на континуативниот перфект, ќе употребат некое од сегашните англиски времиња наместо англискиот перфект. Здравеска (2013) во своето истражување открива дека изучувачите го употребуваат англиското сегашно просто време како замена за англискиот перфект, но не специфицира која перфектна функција притоа ја искажуваат. 
Преносни грешки се очекуваат и при опишување дејство што означува блиско минато. Оваа функција во македонскиот јазик се искажува со минато определено свршено време (аорист) и на тој начин дејството го претставуваме како свршено и го лоцираме во минатото. Следниве примери (Арсова-Николиќ 1980: 271) докажуваат дека во опишувањето дејство од блиско минато, аористот одговара на англискиот перфект.

(17) Каква е йаа врева наgвор? зайраша Глиг̄ор.

Госйоg gojge, рече живо ирислужникой.

(Пусииина, Абаџиев 1961: 156)

'What's that din outside? asked Gligor.

The Lord has come, the attendant said animatedly.'

(Desert, Abadziev: 21)

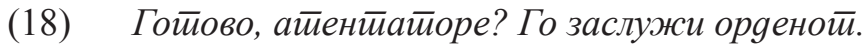

Побрзај наgвор иее чека Ана! - весело заяишан брбореше Глигор.

(Пусииина, Абаџиев 1961: 162)

'Ready, my assassin? You've earned your medal.

Hurry, Ana is waiting outside for you! Gligor babbled, happily, out of breath.' (Desert, Abadziev: 27)

Во МКАМ се среќаваат реченици (19 и 20) во коишто на формата на минато просто време ѝ се припишува функцијата на перфектот на блиско минато.

(19) I am sorry but I now woke up.

'Извини, но сега се разбудив.'

(20) I I just finished looking over the paper you wrote in English.

'Само што завршив со проверување на семинарската што ја напиша на англиски.'

Заради наведените причини и примери, постои можност македонските изучувачи да го употребат англиското минато просто време (past simple) наместо англискиот перфект со намера да опишат дејство од блиското минато. 


\section{2 Контрастирање на англискиот траен перфект (present perfect continuous) и македонскиот перфект}

Откако ги контрастиравме англискиот перфект и македонскиот перфект, на ред е да се осврнеме на англискиот траен перфект (present perfect continuous) и неговите еквиваленти во македонскиот јазик. Англискиот траен перфект не се преклопува со македонскиот перфект по ниту едно значење. За искажување привремена состојба или навика која започнала во минатото и продолжува во сегашноста, македонските говорители го користат македонскиот презент, што значи дека дејството се лоцира во сегашноста (како несвршено). Така, преводен еквивалент на англиската реченица I have been writing this bookfor two years е македонската реченица 'Ја пишувам книгава две години'. Ова непоклопување може да се одрази така што македонските изучувачи ќе ги употребуваат англиските сегашни времиња (present simple и present continuous) за искажување на оваа функција на трајниот перфект. Тоа го потврдува Здравеска (2013) во својот труд. Во нејзиното истражување, сегашно трајно време почесто е употребено од сегашно просто време, како замена за трајниот перфект. Причината за тоа веројатно е фактот што со македонскиот презент се употребуваат трајни (несвршени) глаголи.

Во МКАМ има доста појавувања (21 и 22) на сегашно трајно време во замена за трајниот перфект.

(21) I'm waiting you already 40 minutes.

'Те чекам веќе 40 минути.'

(22) I am learning English seven years.

'Учам англиски седум години.'

Исто така, во корпусот регистрирани се и примери (23 и 24) на употреба на сегашно просто време за да се опише дејство што трае од минатото до сегашниот момент.

(23) I stand here 40 minutes. Where are you?

'Стојам овде 40 минути. Каде си?'

(24) I English language learn eight year.

'Јас го учам англискиот јазик осум години.'

За опишување имплицирана сегашна состојба предизвикана од некое минато дејство, македонските говорители употребуваат минато определено 
несвршено време (имперфект). Така на пример, англиската реченица $I$ have been running for hours имплицира сегашна состојба на измореност. Истата ситуација на македонски јазик, ќе биде претставена со реченицата 'Трчав со часови'. На тој начин, македонските говорители дејството го прикажуваат како минато дејство во одвивање. Аналогно на тоа, се очекува дека македонските изучувачи ќе го употребуваат англиското минато трајно време (кое исто означува минато дејство во одвивање) за искажување на последната функција на трајниот перфект. Изучувачите прво го изучуваат минатото трајно време, а потоа трајниот перфект. Освен тоа, Пеповска (2013) истакнува дека имперфектот е основниот еквивалент на англиското минато трајно време, па според тоа, се очекува дека на пониските нивоа изучувачите ќе користат минато трајно време, наместо траен перфект за да имплицираат сегашна состојба. Такви случаи (25 и 26) се забележани и во MKAM.

I'm so sorry I was sleaping till now.

'Извини спиев досега.'

(26) I was running a lot. I'm very tired.

'Многу трчав. Многу сум изморен.'

Табела 1. Еквиваленти на англискиот перфект во македонскиот јазик

\begin{tabular}{|l|l|}
\hline $\begin{array}{c}\text { Употреби (значења) на англискиот } \\
\text { перфект }\end{array}$ & $\begin{array}{l}\text { Еквиваленти на англискиот перфект } \\
\text { во македонскиот јазик }\end{array}$ \\
\hline \multirow{2}{*}{ Резултативен перфект } & $\begin{array}{l}\text { Сум-перфект } \\
\text { Има-перфект } \\
\text { Трет перфект } \\
\text { Аорист } \\
\\
\text { Имперфект }\end{array}$ \\
\hline \multirow{2}{*}{ Искуствен перфект } & Сум-перфект \\
Континуативен перфект & Има-перфект \\
\hline Перфект на блиско минато & Сегашно време \\
\hline
\end{tabular}


Табела 2. Еквиваленти на англискиот траен перфект во македонскиот јазик

\begin{tabular}{|l|l|}
\hline $\begin{array}{l}\text { Употреби (значења) на англискиот } \\
\text { траен перфект }\end{array}$ & $\begin{array}{c}\text { Еквиваленти на англискиот траен } \\
\text { перфект во македонскиот јазик }\end{array}$ \\
\hline $\begin{array}{l}\text { Дејство што трае од минатото } \\
\text { до сегашниот момент }\end{array}$ & Сегашно време \\
\hline Сегашна состојба & Имперфект \\
\hline
\end{tabular}

Од ова контрастирање се гледа дека перфектот и трајниот перфект, коишто кодираат вид, но не и време, во македонскиот јазик се преведуваат со глаголски форми кои разликуваат и време и вид. Во македонскиот јазик дејството задолжително се лоцира во минато или во сегашно време. Оттаму, македонските изучувачи најчесто трагаат по соодветно англиско минато или сегашно време, наместо да ги употребат перфектот и трајниот перфект, коишто изразуваат релација меѓу минатото и сегашноста. Резултатите од контрастивната анализа се сумирани во табелите 1 и 2.

\section{5 Заклучок}

Како заклучок ги сумирам сличностите и разликите помеѓу конструкции со перфект во двата јазика. Исто така, ги наведувам конкретните претпоставки за импликациите на овие релации врз процесот на усвојување на перфектот и трајниот перфект. Оваа статија се базира на општата хипотеза дека мајчиниот јазик влијае врз процесот на усвојување на англискиот перфект и англискиот траен перфект од страна на македонските изучувачи. Се претпоставува дека значењата на англискиот перфект што се преклопуваат со значењата на македонскиот перфект ќе бидат полесно усвоени. Таков е случајот со искуствениот перфект. Англискиот искуствен перфект се преведува со македонскиот сум-перфект или има-перфект како на пр. Sam has travelled to many countries. 'Сем патувал/има патувано во многу земји'. Со оглед на тоа што перфектот и во македонскиот и во англискиот јазик искажува искуство (ситуација која се случила барем еднаш во некој недефиниран момент во минатото), постои претпоставка дека македонските изучувачи најлесно ќе го совладаат ова значење.

Од друга страна, повеќе грешки се очекуваат кај оние значења на англискиот перфект кои во македонскиот јазик не се изразуваат со перфектот. Така, англискиот резултативен перфект се преведува со македонскиот т.н. трет перфект, како на пр. They have arrived. 'Тие се пристигнати'. Меѓутоа, минато определено свршено време во македонскиот јазик, исто така, 
искажува резултативност. Според тоа, оваа англиска реченица би можела да се преведе и на следниов начин: ‘Тие пристигнаа'. Англискиот резултативен перфект може да се преведе и со македонскиот сум-перфект или имаперфект, како на пр. I have lost the key. 'Сум го загубила клучот' или 'Го имам загубено клучот’. Во овој случај англиската реченица повторно може да се преведе со минато определено свршено време на следниов начин: 'Го загубив клучот'. Бидејќи македонското минато свршено време во многу случаи се поклопува со англиското минато просто време (past simple), постои можност македонските изучувачи да го заменат англискиот перфект со англиското минато просто време за да искажат резултативност.

Се очекува македонските изучувачи да имаат тешкотии кога се работи за дејство што започнало во минатото и продолжува да трае во сегашноста. Во македонскиот јазик за искажување на истата функција се користи сегашно време. Според тоа, англиската реченица I have studied English since I was six би се превела на следниов начин: 'Учам англиски од мојата шеста година'.

Исто така, се претпоставува дека македонските изучувачи ќе се соочат со проблеми кога ќе треба да искажат дејство кое се случило во блиското минато. Во овој случај, англискиот перфект најчесто е придружуван од прилогот just ('само што', 'туку што'). He has just left. 'Тој само што замина'. Како што може да се забележи, во вакви ситуации, во македонскиот јазик се употребува минато определено свршено време (аорист).

Дополнителен проблем за македонските изучувачи може да биде англискиот траен перфект, кога со него се искажува дејство што трае од минатото до сегашниот момент: I have been stydying Spanish for one year. Ова значење во македонскиот јазик се предава со сегашно време: 'Учам шпански една година'. Можеме да предвидиме дека за македонските изучувачи тешко ќе биде и усвојувањето на другото значење на трајниот перфект - сегашна состојба. За искажување на ова значење, во македонскиот јазик го употребуваме минато определено несвршено време (имперфект). Така на пример, англиската реченица I have been working all day би се превела како што следува: 'Работев цел ден'. Во зависност од контекстот, во македонскиот превод може да се употреби и сегашно време: 'Мртва сум уморна, работам цел ден (до сега)’. Употребата на трајниот перфект се очекува на повисоките нивоа на познавање на јазикот.

Одредени хипотези може да се формираат и во поглед на усвојувањето на формата на англискиот перфект и на англискиот траен перфект. Постои претпоставка дека изучувачите на пониските нивоа ќе прават грешки во формата на перфектот. Тоа може да бидат грешки во формата на помошниот глагол и/или минатиот партицип. На повисоките нивоа би требало да се изгубат ваквите грешки. Како што беше претходно споменато, примената на трајниот перфект се очекува само на повисоките нивоа. Од таа причина, 
можни се грешки во формата на трајниот перфект само на повисоките нивоа. Може да се работи за грешки во формата на помошните глаголи и/ или сегашниот партицип. Сепак, се претпоставува дека ваквите грешки не се чести и дека формата на трајниот перфект е усвоена од страна на изучувачите на повисоките нивоа на познавање на јазикот.

\section{Библиографија}

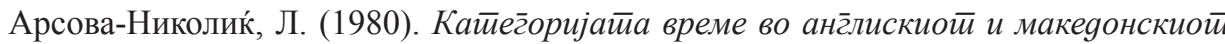
глаг̄олски систием. Докторски труд. Скопје: Универзитет „Св. Кирил и Методиј“. Здравеска, Д. (2013). Улог̄айа на меѓујазичнойо влијание во усвојувањетио на анг̄лискийе сег̄ашни времиња (present simple and present continuous) og

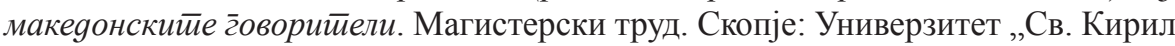
и Методиј“.

Конески, Б. (1987). Грамайика на макеgонскиой литерайурен јазик. Скопје: Култура.

Митковска, Л. и Бужаровска, Е. (2011). За употребата на има-перфектот во македонскиот стандарден јазик во релација со конкурентните глаголски форми.

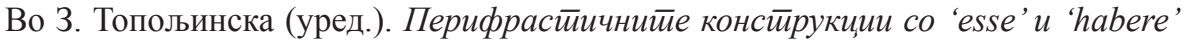
во словенскийе и балканскийе јазици, 55-82. Скопје: МАНУ.

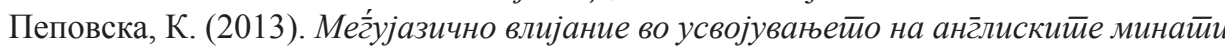
времиња (past simple tense and past continuous tense) og макеgонски говорииеели. Магистерски труд. Скопје: Универзитет „Св. Кирил и Методиј“.

Bužarovska, E. and Mitkovska, L. (2010). The grammaticalization of the habere-perfect in Standard Macedonian. Balkanistica, 23: 75-97.

Comrie, B. (1976). Aspect: An introduction to the study of verbal aspect and related problems. Cambridge: Cambridge University Press.

Graves, N. (2000). Macedonian - a language with three perfects? In Ö. Dahl (ed.). Tense and aspect in the languages of Europe, 479-494. Berlin: Mouton de Gruyter.

Quirk, R., Greenbaum, S., Leech, G. and Stvartvik, J., (1985). A comprehensive grammar of the English language. London: Longman.

Mitkovska, L. and Bužarovska, E. (2008). On the use of habere-perfect in journalistic and administrative style. STUF, 61(2): 128-138.

Radden, G. and Dirven, R. (2007). Cognitive English grammar. Amsterdam/Philadelphia: John Benjamins. 